\title{
Research On Monetary Neutrality: Evidence From Exchange Rate And Trade Balance Of G-7 Countries
}

Doh-Khul Kim, Mississippi State University, Meridian

\begin{abstract}
According to a recent paper by Fisher and Huh (2002), in contrast to a long-run neutrality hypothesis, nominal shocks have long-run effects on a country's real exchange rate and trade balance. However employing a similar method (VAR) with identical restrictions (long-run neutrality and short-run recursive hypotheses), this paper shows that the effects on the real exchange rate are much shorter in this G-7 country study than what Fisher and Huh (2002) contend. Further, the trade balance improves for a short period of time, from which it can conclude there is a shorter existence of the depreciation effect in response to expansionary monetary shocks, which supports the long-run neutrality hypothesis in an open macroeconomic framework.
\end{abstract}

\section{INTRODUCTION}

umerous studies show aggregate economic activities in response to exogenous disturbances. One of
the popular methods these studies adopt is a structural vector autoregression (VAR) framework,
which has emerged as an important empirical tool in recent time-series macroeconomics thanks to convenient representation and easy estimation of the variables without any concern regarding endogeneity problems. Thus, the VAR framework is widely and frequently used in the study of macroeconomic variables for their interrelationships and responses, especially in the short run. However, such structural VAR models normally require several assumptions and restrictions to better identify the responses of the variables to exogenous shocks such as aggregate demand and nominal shocks. One of the most widely accepted restrictions is a long-run neutrality restriction of nominal variables that has no permanent effect on the levels of real variables by any nominal shocks such as monetary shocks. ${ }^{1}$ This long-run hypothesis does not rely on any particular monetary policy rule, but rather on a basic assumption underlying almost all monetary macroeconomic models.

However, recent studies show that such a long-run neutrality is not empirically valid, and argue that there are persistent long-run effects on real variables by nominal shocks. (Fisher and Seater 1993, Coe and Nason 2003) In their frequently cited analysis which uses U.S. data over the 1869-1975 period, Fisher and Seater (1993) report results that reject the long-run neutrality of money. ${ }^{2}$ In their recent study using both the long-horizon regression test of Fisher and Seater (1993) and the inverse power function of Andrews (1989), Coe and Nason (2003) show results that weakly support the monetary neutrality. Further, Fisher and Huh (2002) even show the long-run effects by nominal shocks on the real variables. They argue that the fact there are no long-run effects on real variables by nominal shocks should be primarily attributed to the restriction (long-run neutrality) itself employed in the empirical models. Therefore, once the assumption is relaxed and substituted in with an alternative restriction (contemporaneous restriction) ${ }^{3}$ it can identify the persistent effects on real economic variables made by even nominal shocks, which is in contrast to much previous research. Hence, more needs to be debated. ${ }^{4}$

The main purpose of this research is to demonstrate if such nominal shocks, specifically monetary shocks, have any long-run effects on real variables. To this end, this paper researches monetary neutrality, giving the greatest attention to the responses of real exchange rate and trade balance of G-7 countries because many show results that are empirically consistent but sometimes inconsistent with the long-run monetary neutrality in aggregate 
variables such as output and employment. (Boschen and Otrok 1994, Haug and Lucas 1997) Thus, the findings in this research are expected to provide (i) the empirical validity of the long-run neutrality hypothesis in the framework of open macroeconomics and (ii) a valuable insight into the interactions of money and real variables in open macroeconomic models. This paper finds there is no (substantially) persistent effect on both real exchange rate and trade balance, which may confirm the empirical validity of the long-run neutrality and Mundell-Flemming model with a long-run assumption of Purchasing Power Parity (PPP). ${ }^{5}$ In addition, in this cross-country study, it shows there is no long-run depreciation of a currency with short-run effects on trade balance even after controlling for an output (or income-absorption) effect by expansionary monetary shocks. This study differs from previous papers in the following ways: (i) as mentioned before, the shock (money supply shock) is more specific than in other previous research mainly for easier and better identification of the nominal shocks; (ii) it uses both long-run and short-run recursive restrictions to critiques such as Fisher and Huh (2002); and (iii) it employs more variables (real exchange rate, trade balance, real output, interest rate, real money stocks and nominal money stocks) appropriate for this VAR model to see if the models in this research and assumptions are reasonable enough by confirming that the responses of the other variables are consistent with stylized facts. ${ }^{6}$ (Christiano, Eichenbaum, and Evans, CEE, 1997)

Even though some argue that any time-series models that focus only on one source of shocks will result in an incomplete model because many macroeconomic variables including the real exchange rate and trade flows can be affected by many different shocks, this paper provides the empirical validity of the long-run neutrality hypothesis regarding one nominal shock (monetary shock). Further, the following results show substantial variations in the responses of the variables due to different economic environments across the countries. However, no further explanations regarding such variations are provided here because it is beyond the main purpose of this research (even though it is worth discussing). This paper consists of (i) empirical methods in section 2 followed by dynamic responses with a long-run hypothesis in section 3; (ii) dynamic responses with a contemporaneous restriction in section 4; (iii) forecast error variance decomposition in section 5; and (iv) final comments in section 6.

\section{EMPIRICAL METHODS FOR LONG-RUN NEUTRALITY HYPOTHESIS}

\section{II.1. VAR And Identification}

Let vector $Z_{t}$ contain 6 variables, which are generated by the following structural model;

$$
A_{0} Z_{t}=A_{1} Z_{t-1}+A_{2} Z_{t-2}+\ldots .+A_{p} Z_{t-p}+u_{t}
$$

where $Z_{t}$ contains real exchange rate $\left(\Delta e_{t}\right)$, trade balance $\left(\Delta b_{t}\right)$, real output $\left(\Delta y_{t}\right)$, nominal interest rate $\left(\Delta \boldsymbol{r}_{t}\right)$, real money supply $\left(\Delta_{\boldsymbol{m}_{t}}\right)$, and nominal money supply $\left(\Delta \boldsymbol{M}_{t}\right) \cdot \boldsymbol{U}_{t}(6 \times 1$ vector $)$ is mutually uncorrelated white-noise disturbance with $E U_{t} U_{t}=$ I (identity matrix). ${ }^{7}$ The variables are differenced once to impose stationarity, a valid transformation if the elements of $Z_{t}$ have single unit roots. The equation (1), structural VAR, is not estimable directly and the model to be estimated is a reduced form of VAR as follows;

$$
Z_{t}=B_{1} Z_{t-1}+B_{2} Z_{t-2}+\ldots .+B_{p} Z_{t-p}+\varepsilon_{t}
$$

where $B_{t}=A_{0}^{-1} A_{t}, \varepsilon_{t}=A_{0}^{-1} u_{t}$, and $E \varepsilon_{t} \varepsilon_{t}^{\prime}=\sum=A_{0}^{-1} A_{0}^{-1^{\prime}}$.

Using a lag operator, $\mathrm{L}$, the equation (1) and (2) can be reexpressed as follows;

$Z_{t}=\mathrm{D}(\mathrm{L}) u_{t}$

$Z_{t}=C(L) \varepsilon_{t}$ 
Utilizing the OLS estimation of the VAR in equation (2) and (4), C(L) (reduced-form parameters) and $\Sigma$ (6×6 variance and covariance matrix of $\mathcal{E}_{t}$ ) will be obtained. However, it needs to restrict the structual form in order to fully recover the structural coefficients in (1) and (3), and the restriction employed in this study is the commonly used long-run monetary neutrality. Then, this approach will result in a reliable identification of $\mathrm{D}(\mathrm{L})$ of equation (3), which is the main purpose of this research.

\section{II.2. Data}

The data used in this research are from 'OECD Main Economic Indicators' and quarterly observations of G-7 countries. The data (from 1973 through 2000) depending on availability are as follows: exchange rate against the US, ${ }^{8}$ trade balance, GDP at constant prices, short-term interest rates, and money supply (M1/M2). ${ }^{9}$ This paper uses a consumer price index (CPI) to deflate the nominal variables. All the variables except for the trade balance and interest rate take the form of logarithms, and all that have single unit roots are differenced once following the augmented Dicky-Fuller (ADF) test and Phillips-Perron (PP) test.

Table 1: Augmented Dickey-Fuller (ADF) and Phillips-Perron (PP) Tests for G-7Countries

\begin{tabular}{|c|c|c|c|c|c|c|c|}
\hline & Test & $\begin{array}{c}\text { Trade } \\
\text { Balance }\end{array}$ & $\begin{array}{c}\text { Real } \\
\text { Output }\end{array}$ & $\begin{array}{c}\text { Interest } \\
\text { Rate }\end{array}$ & $\begin{array}{l}\text { Real Money } \\
\text { Supply }\end{array}$ & $\begin{array}{c}\text { Nominal } \\
\text { Money } \\
\text { Supply }\end{array}$ & $\begin{array}{c}\text { Real } \\
\text { Exchange } \\
\text { Rate }\end{array}$ \\
\hline \multirow{2}{*}{ Canada } & ADF Test & $\begin{array}{c}-3.491 \\
(-12.734)\end{array}$ & $\begin{array}{c}-1.446 \\
(-9.939)\end{array}$ & $\begin{array}{c}-0.785 \\
(-8.651)\end{array}$ & $\begin{array}{c}-0.490 \\
(-7.918)\end{array}$ & $\begin{array}{c}-1.433 \\
(-9.154)\end{array}$ & $\begin{array}{c}-2.179 \\
(-8.801)\end{array}$ \\
\hline & PP Test & $\begin{array}{c}-8.880 \\
(-43.470)\end{array}$ & $\begin{array}{c}-1.023 \\
(-30.894) \\
\end{array}$ & $\begin{array}{c}-0.857 \\
(-14.721) \\
\end{array}$ & $\begin{array}{c}-0.444 \\
(-21.467) \\
\end{array}$ & $\begin{array}{c}-1.465 \\
(-23.147) \\
\end{array}$ & $\begin{array}{c}-2.195 \\
(-18.538) \\
\end{array}$ \\
\hline \multirow{2}{*}{ France } & ADF Test & $\begin{array}{c}-2.423 \\
(-13.261)\end{array}$ & $\begin{array}{c}-2.393 \\
(-5.044)\end{array}$ & $\begin{array}{c}-2.182 \\
(-6.793)\end{array}$ & $\begin{array}{c}-2.088 \\
(-5.461)\end{array}$ & $\begin{array}{c}-0.970 \\
(-7.043)\end{array}$ & $\begin{array}{c}-2.607 \\
(-5.868)\end{array}$ \\
\hline & PP Test & $\begin{array}{c}-8.917 \\
(-49.681)\end{array}$ & $\begin{array}{c}-2.120 \\
(-17.246)\end{array}$ & $\begin{array}{c}-1.986 \\
(-14.367)\end{array}$ & $\begin{array}{c}-2.278 \\
(-20.623)\end{array}$ & $\begin{array}{c}-0.998 \\
(-26.071)\end{array}$ & $\begin{array}{c}-2.523 \\
(-11.184)\end{array}$ \\
\hline \multirow{2}{*}{ Germany } & ADF Test & $\begin{array}{c}-2.225 \\
(-13.346)\end{array}$ & $\begin{array}{c}-1.987 \\
(-6.457)\end{array}$ & $\begin{array}{c}-2.506 \\
(-7.136)\end{array}$ & $\begin{array}{c}-1.484 \\
(-6.760)\end{array}$ & $\begin{array}{c}-1.711 \\
(-7.495)\end{array}$ & $\begin{array}{c}-1.954 \\
(-7.758)\end{array}$ \\
\hline & PP Test & $\begin{array}{c}-5.004 \\
(-40.704)\end{array}$ & $\begin{array}{c}-2.740 \\
(-12.137)\end{array}$ & $\begin{array}{c}-2.154 \\
(-11.392)\end{array}$ & $\begin{array}{c}-1.636 \\
(-15.533)\end{array}$ & $\begin{array}{c}-1.716 \\
(-16.948)\end{array}$ & $\begin{array}{c}-1.881 \\
(-12.542)\end{array}$ \\
\hline \multirow{2}{*}{ Italy } & ADF Test & $\begin{array}{c}-2.994 \\
(-12.924)\end{array}$ & $\begin{array}{c}-0.678 \\
(-7.823)\end{array}$ & $\begin{array}{c}-1.936 \\
(-5.095)\end{array}$ & $\begin{array}{c}-1.262 \\
(-5.837)\end{array}$ & $\begin{array}{c}-1.003 \\
(-7.103)\end{array}$ & $\begin{array}{c}-1.691 \\
(-6.165)\end{array}$ \\
\hline & PP Test & $\begin{array}{c}-6.464 \\
(-43.052)\end{array}$ & $\begin{array}{c}-0.865 \\
(-21.116)\end{array}$ & $\begin{array}{c}-1.640 \\
(-9.127)\end{array}$ & $\begin{array}{c}-1.417 \\
(-16.749)\end{array}$ & $\begin{array}{c}-1.170 \\
(-18.623)\end{array}$ & $\begin{array}{c}-1.929 \\
(-10.125)\end{array}$ \\
\hline \multirow{2}{*}{ Japan } & ADF Test & $\begin{array}{c}-2.415 \\
(-15.515) \\
\end{array}$ & $\begin{array}{c}-1.769 \\
(-7.660) \\
\end{array}$ & $\begin{array}{c}-2.593 \\
(-8.920) \\
\end{array}$ & $\begin{array}{c}-2.172 \\
(-5.725) \\
\end{array}$ & $\begin{array}{c}-2.531 \\
(-6.253) \\
\end{array}$ & $\begin{array}{c}-2.321 \\
(-7.042) \\
\end{array}$ \\
\hline & PP Test & $\begin{array}{c}-4.082 \\
(-34.060)\end{array}$ & $\begin{array}{c}-2.122 \\
(-17.886)\end{array}$ & $\begin{array}{c}-2.802 \\
(-15.142)\end{array}$ & $\begin{array}{c}-1.722 \\
(-13.734)\end{array}$ & $\begin{array}{c}-3.502 \\
(-16.738)\end{array}$ & $\begin{array}{c}-2.024 \\
(-12.574)\end{array}$ \\
\hline \multirow{2}{*}{ UK } & ADF Test & $\begin{array}{c}-3.076 \\
(-13.462)\end{array}$ & $\begin{array}{c}-2.872 \\
(-11.932)\end{array}$ & $\begin{array}{c}-1.553 \\
(-8.659)\end{array}$ & $\begin{array}{c}-0.927 \\
(-4.851)\end{array}$ & $\begin{array}{c}-0.658 \\
(-3.548)\end{array}$ & $\begin{array}{c}-2.782 \\
(-8.836)\end{array}$ \\
\hline & PP Test & $\begin{array}{c}-7.075 \\
(-42.564) \\
\end{array}$ & $\begin{array}{c}-2.845 \\
(-30.484) \\
\end{array}$ & $\begin{array}{c}-1.339 \\
(-14.311) \\
\end{array}$ & $\begin{array}{c}-0.587 \\
(-12.644) \\
\end{array}$ & $\begin{array}{c}-0.118 \\
(-12.656) \\
\end{array}$ & $\begin{array}{c}-2.631 \\
(-13.916) \\
\end{array}$ \\
\hline \multirow{2}{*}{ US } & ADF Test & $\begin{array}{c}-3.014 \\
(-10.843)\end{array}$ & $\begin{array}{c}-1.974 \\
(-8.991) \\
\end{array}$ & $\begin{array}{c}-1.044 \\
(-8.406)\end{array}$ & $\begin{array}{c}-1.448 \\
(-8.082)\end{array}$ & $\begin{array}{c}-2.354 \\
(-8.440) \\
\end{array}$ & $\begin{array}{c}-2.010 \\
(-10.511)\end{array}$ \\
\hline & PP Test & $\begin{array}{c}-5.693 \\
(-40.086)\end{array}$ & $\begin{array}{c}-1.832 \\
(-26.168)\end{array}$ & $\begin{array}{c}-1.078 \\
(-14.732)\end{array}$ & $\begin{array}{c}-1.354 \\
(-20.112)\end{array}$ & $\begin{array}{c}-2.405 \\
(-20.396)\end{array}$ & $\begin{array}{c}-1.875 \\
(-15.451)\end{array}$ \\
\hline
\end{tabular}

Notes: The numbers in parenthesis indicate t-value for first differenced variables, and each t-value in the upper row accepts the unit root hypothesis while the t-value in parenthesis rejects the hypothesis at 5\% significance level. Thus, the table shows that all countries have single unit roots in their variables except for trade balance. 
However, some countries have single unit roots in the trade balance (according to the PP test) while others do not. In this case, this paper runs the estimation employing both differenced and non-differenced trade balance to better compare the results, but no significant difference is found here. ${ }^{10}$ An Engle-Granger procedure is used to check if there are any long-term relationships among the variables and no cointegrating relationship is found here.

Table 2: Cointegration Test with Engle-Granger Procedure

\begin{tabular}{|c|c|c|c|c|c|c|}
\hline Canada & France & Germany & Italy & Japan & UK & USA \\
\hline-3.52 & -3.25 & -1.81 & -1.42 & -2.67 & -3.77 & -2.88 \\
\hline
\end{tabular}

Notes: The left-hand-side variable in this procedure is the real exchange rate. The numbers indicate the t-statistics of augmented Dickey-Fuller test of the residual of the real exchange rate that is regressed against remaining variables and first differenced. The table shows that they contain a unit root even after the first-difference, from which it can conclude the sequences are not cointegrated at $5 \%$ significance level (critical value $=-4.58)$.

The leg lengths for the variables range from 2 to 7 according to the likelihood ratio and AIC/SBC tests. In addition, Ljung-Box Q-statistics is adopted to see if the residuals from an estimated VAR model behave as a whitenoise process and no significant autocorrelation is found.

\section{IMPULSE RESPONSE FUNCTIONS WITH LONG-RUN RESTRICTIONS}

According to the traditional Mundell-Flemming model, a monetary expansion will result in a depreciation of the nominal exchange rate and a deterioration in the terms of trade. Such activities will then lead to an improvement in the trade balance, which is regarded as the expenditure-switching (or depreciation) effect. In addition, such an expansion in money supply will induce an output effect, which will result in a worsening of the trade balance with a higher domestic demand for foreign goods, which is regarded as the income-absorption (or output) effect. Therefore, the trade balance may improve or deteriorate depending on the relative dominance of those two effects.

Figure 1-a. Responses to Money Supply Shocks-LR Restrictions

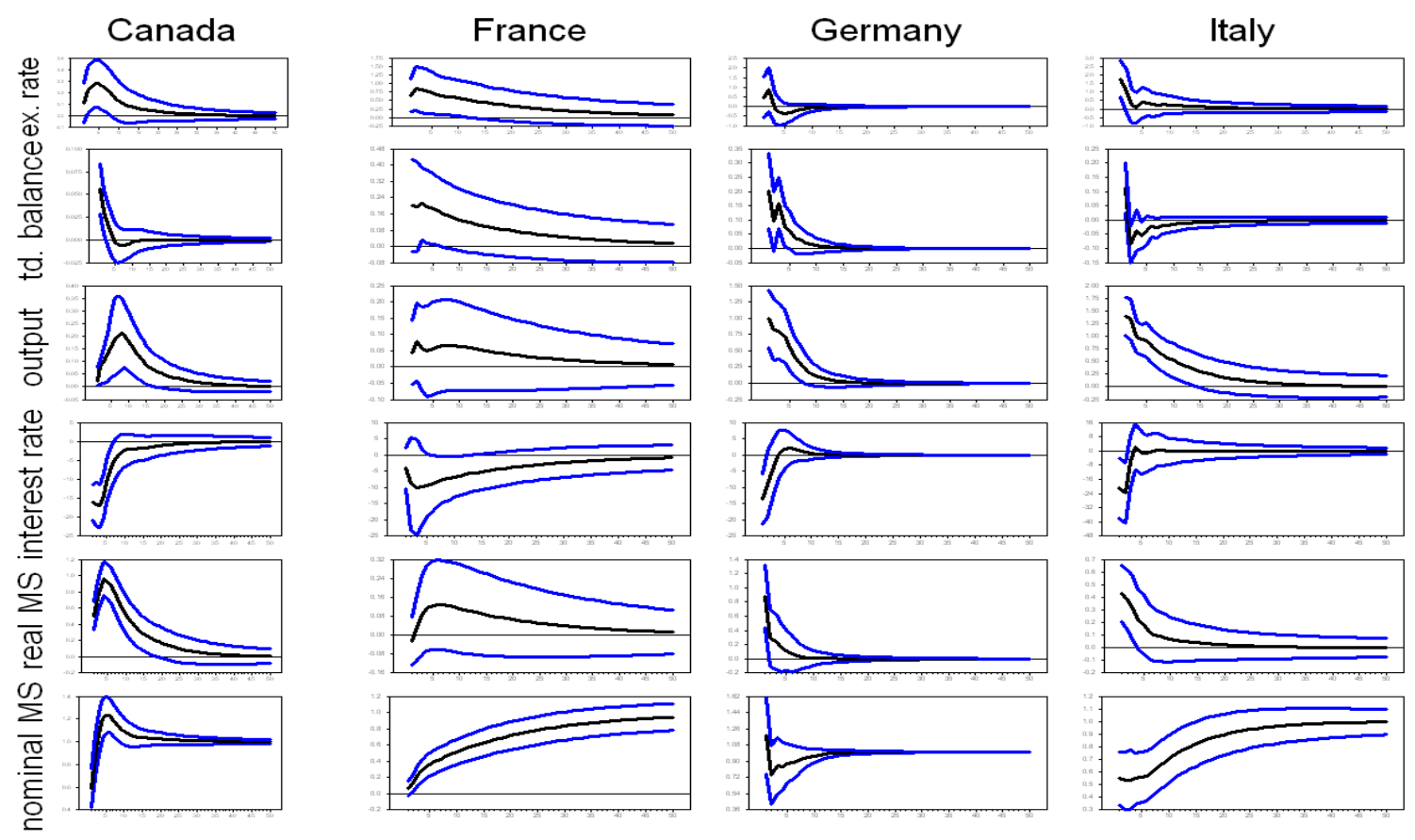


Figure 1-b. Responses to Money Supply Shocks-LR Restrictions
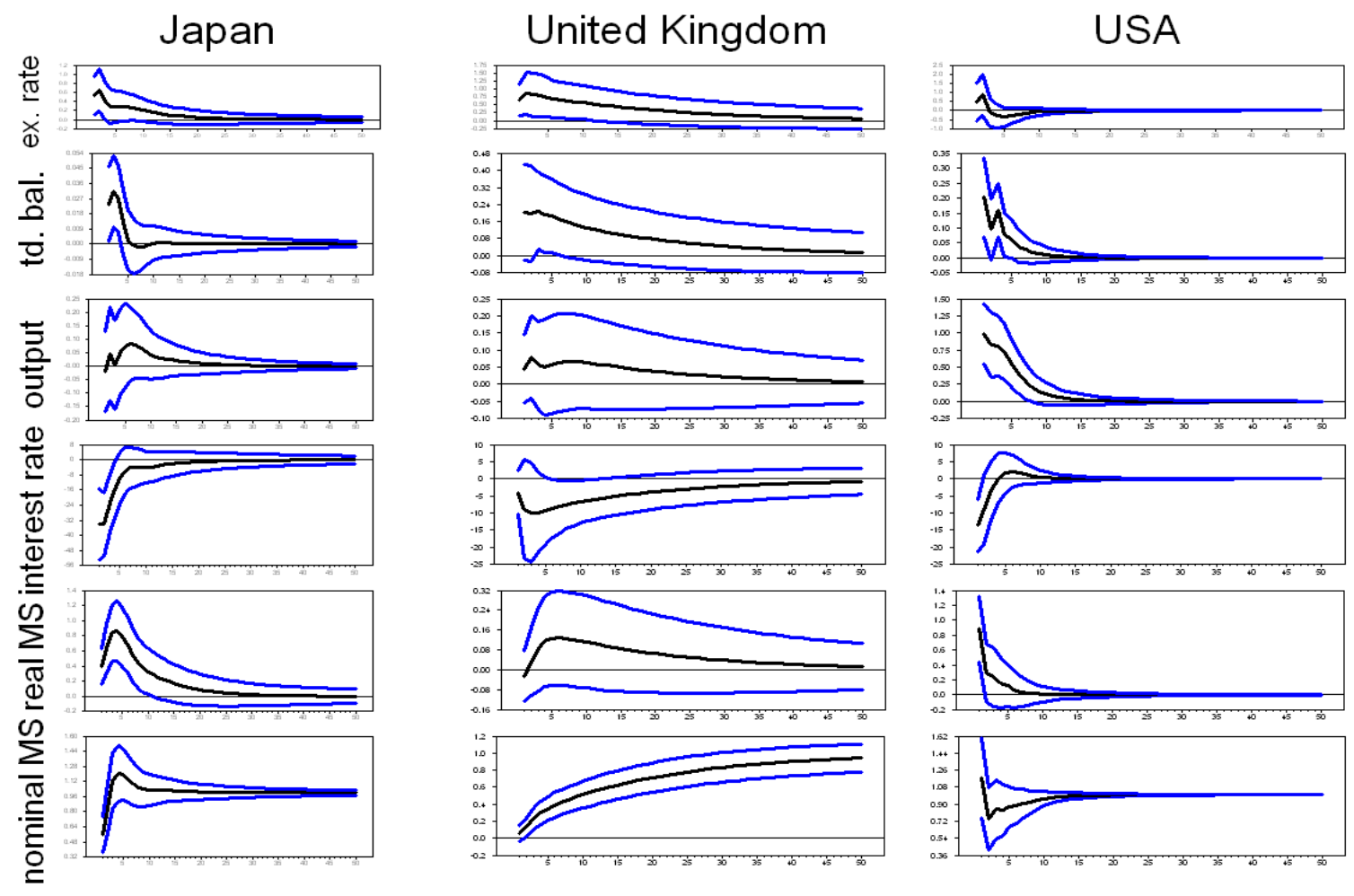

The impulse responses in figure 1-a and 1-b show that the expenditure-switching effect is more dominant with significant improvement in the trade balance across the G-7 countries. ${ }^{11}$

However, this dominance and responses do not last long primarily due to the long-run neutrality restrictions imposed here and the interactions of both the expenditure-switching and output effects. Even when the restrictions are taken into account, the responses in the real exchange rate and trade balance last much shorter than the findings in some of the previous papers such as those by Prasad and Gable (1998) and Fisher and Huh (2002), except for France and UK, whereas the responses in the remaining variables confirm previous findings generally accepted in macroeconomics, including a liquidity effect. ${ }^{12}$ Hence, this paper can claim: (i) the expenditure-switching effect dominates the income-absorption effect in the short run; and (ii) the responses last only for a short period of time (mainly due to the restriction) including the ones in the real exchange rate. However, the results may be susceptible to critiques because of the restriction itself and the fact it does not control for any output effect. Thus, this paper first re-estimates the basic model by taking the ratio of the trade balance to GDP to partially control for any domestic income-absorption (or output) effect for the responses in the trade balance as suggested by Prasad (1999) and Fisher and Huh (2002). (Figure 2)

Figure 2 demonstrates there is no substantial and qualitative difference from the previous figures as they show that the improvements in trade balance across the countries last a little bit longer, but die away rather more quickly than the theory predicts. ${ }^{13}$ Thus, no long-run effects on the trade balance by nominal shocks exist even after the output effect is controlled. 
Figure 2. Responses of Trade Balance to Money Supply Shocks
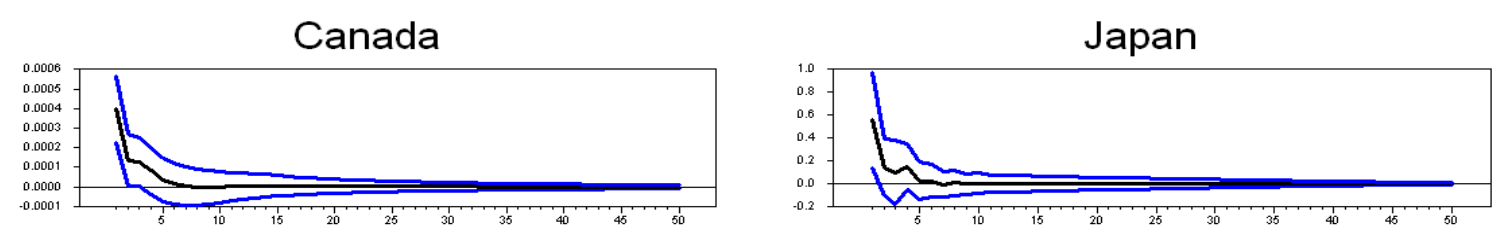

France
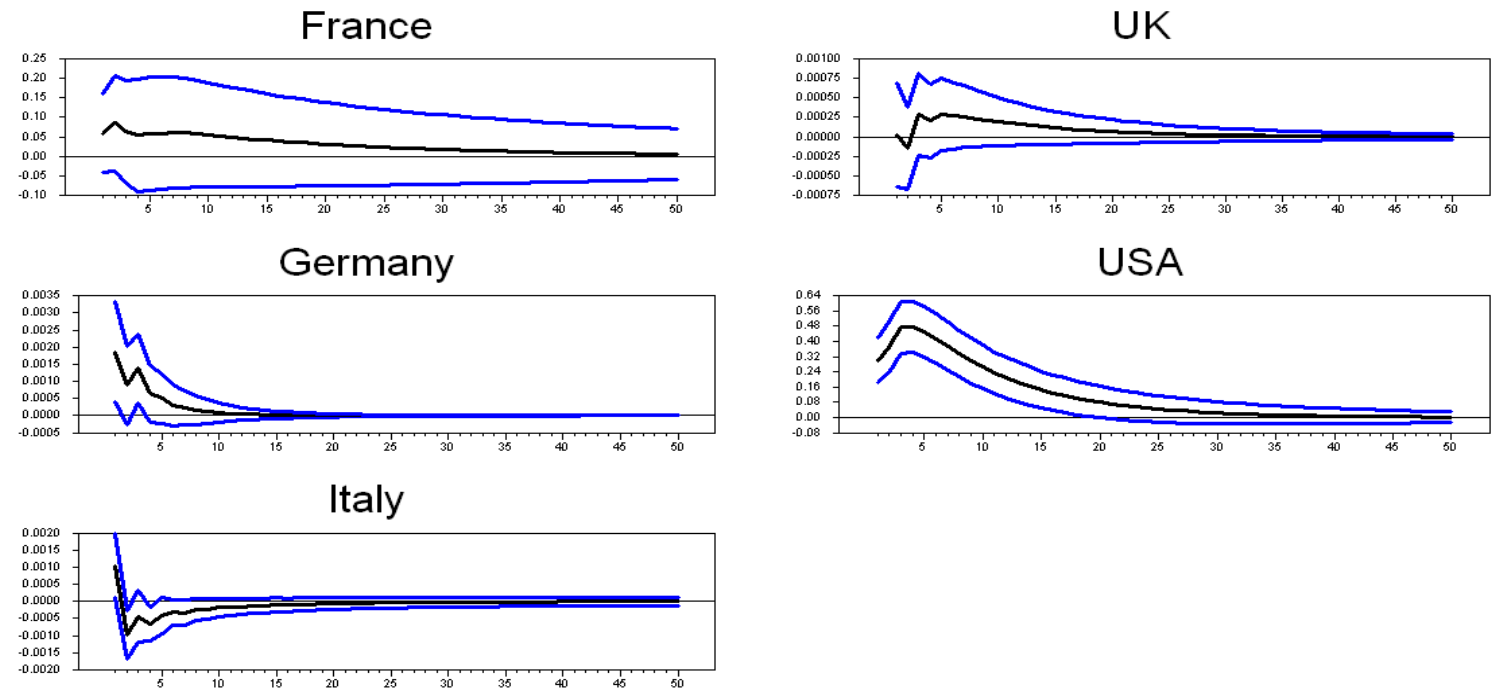

\section{CONTEMPORANEOUS RESTRICTION}

\section{IV.1. Identification}

The paper re-estimates the model imposing an alternative identifying restriction (short-run recursive restriction) in an attempt to build a model that can better identify the dynamic responses of the variables to monetary shocks. As mentioned before, even though such a long-run neutrality restriction is widely accepted in recent timeseries research employing finite data sets, some economists argue that the results are sensitive to the way the shocks are identified. (Faust and Leeper 1997, Cooley and Dwyer 1998) Gali (1992) and Kim (1999) also propose that both long-run and short-run restrictions need to be imposed to better separate the money supply shocks. Further, Fisher and Huh (2002) argue that we cannot see the long-run real effects of nominal shocks because of the long-run neutrality restriction itself imposed on the model. Therefore, this paper tries to identify such monetary shocks and responses imposing an alternative restriction (contemporaneous restriction) following the work of CEE (1997). The short-run recursive restriction depends only on contemporaneous relationships among the variables, and no firstdifference of any non-stationary variable is required. ${ }^{14}$

Let vector $Z_{t}$ contain $Z_{1 t}\left(y_{t}, P_{t}, e_{t}, b_{t}\right), S_{t}\left(\boldsymbol{r}_{t}\right)$, and $Z_{2 t}\left(M_{t}\right){ }^{15}$ The monetary authority is assumed to see $y_{t}\left(\log\right.$ of real GDP), $\boldsymbol{P}_{t}(\log$ of CPI $), \boldsymbol{e}_{t}\left(\log\right.$ of real exchange rate), and $\boldsymbol{b}_{t}$ (trade balance) ${ }^{16}$ when $S_{t}$ (indicating monetary policy shock) is decided. In addition, the monetary policy shock is orthogonal to the elements in $Z_{1 t}$ and all the elements will respond only with a lag. As CEE (1997) explained, a central bank in each country has at its disposal monthly (or quarterly) data on aggregate output, price, exchange rate and trade balance even though this assumption is controversial. (Kim 1999) ${ }^{17}$ The $\boldsymbol{r}_{t}$ (short-term interest rate) ${ }^{18}$ and $M_{t}(\log$ of money stock) variables are assumed not to affect any variables in $Z_{1 t}$ contemporaneously. $\left(\boldsymbol{D}_{12}=\boldsymbol{D}_{13}=0\right)$ It is 
further assumed that the policy makers do not identify any variable in $Z_{2 t}$ when monetary policy $\left(S_{t}\right.$ ) is set, and the variable is only available with a lag. $\left(\boldsymbol{D}_{23}=0\right)^{19}$

Thus, the dynamic responses to monetary shocks, $D_{0}$, can be expressed as follows;

$$
D_{0}=\frac{\delta Z_{t}}{\delta u_{t}}=\left[\begin{array}{lll}
D_{11} & 0 & 0 \\
D_{21} D_{22} & 0 \\
D_{31} & D_{32} & D_{33}
\end{array}\right]
$$

The recursive assumption (zero restrictions in matrix $\boldsymbol{D}_{0}$ ) is sufficient enough to identify the dynamic responses of the variables in $Z_{t}$ to monetary shocks.

\section{IV.2. Dynamic Responses}

Figure 3. Responses of Real Exchange Rate to MS Shocks - SR Restrictions
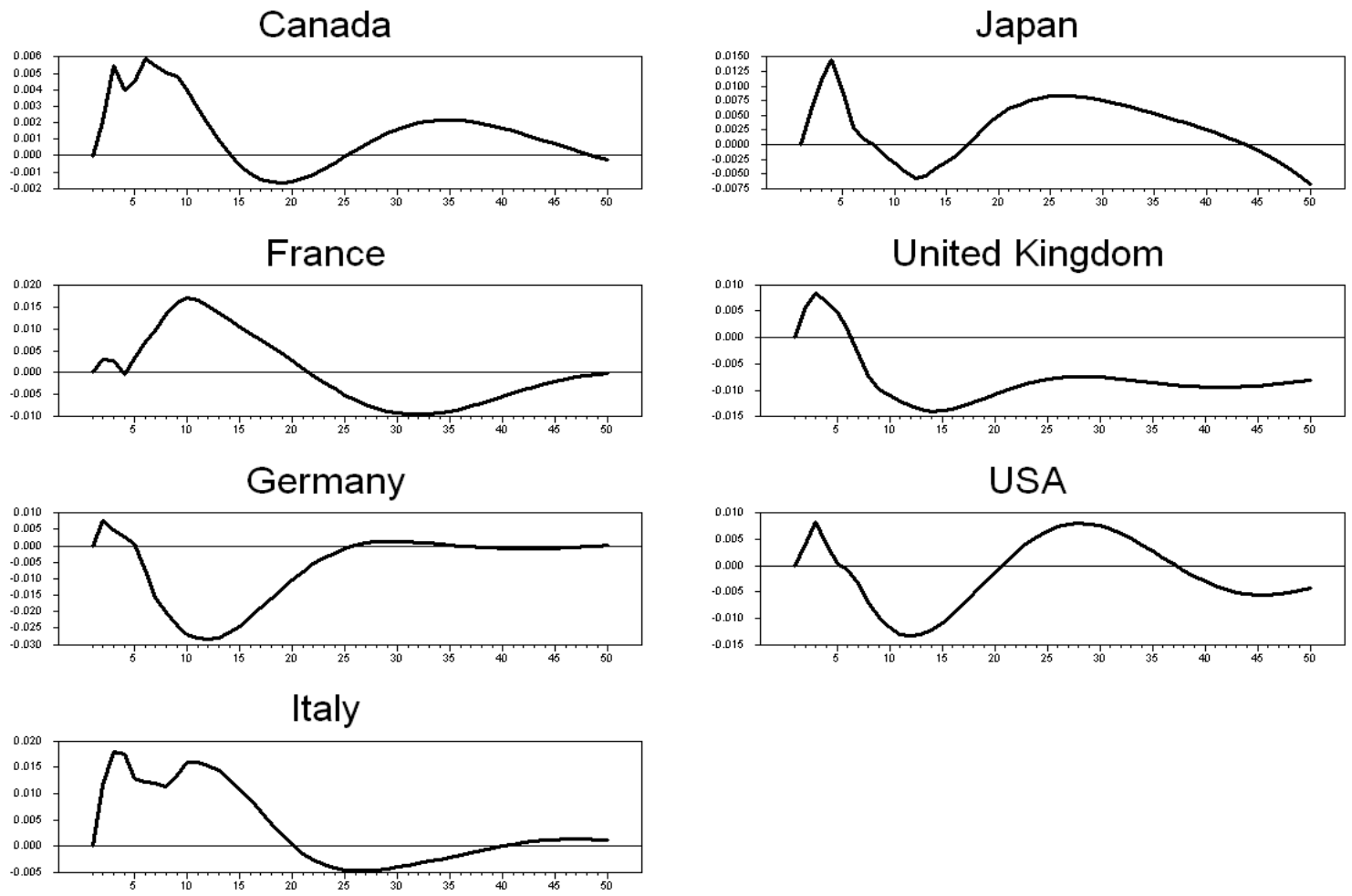


\section{Figure 4. Responses of Trade Balance to MS Shocks - SR Restrictions}

Canada

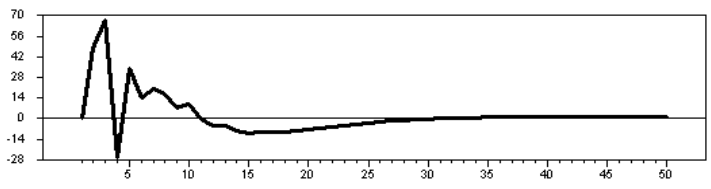

France

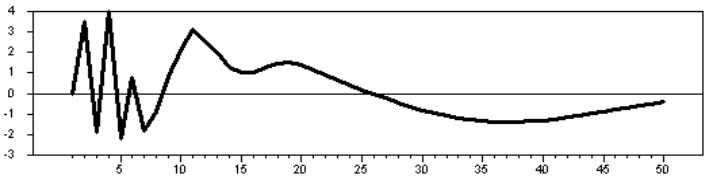

Germany

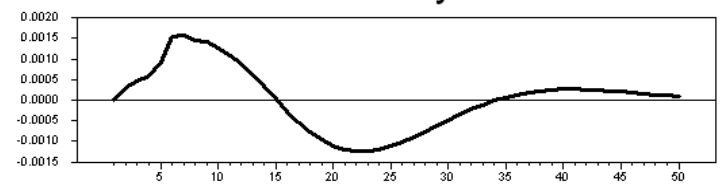

Italy

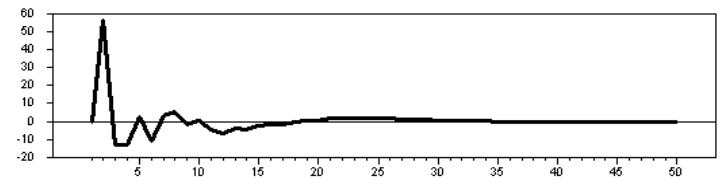

Japan

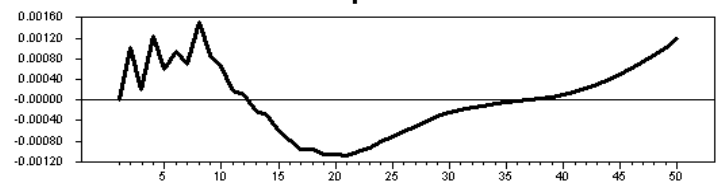

United Kingdom

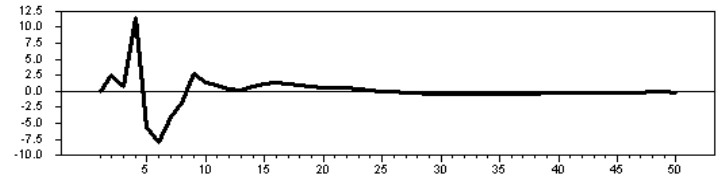

USA

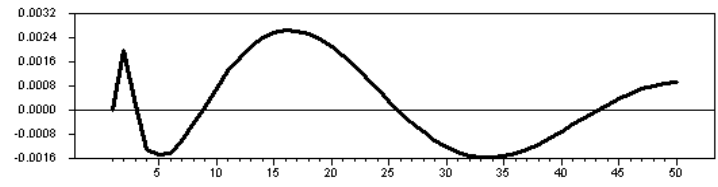

Figure 3 and 4 show the impulse responses of the real exchange rate and trade balance to the same expansionary monetary shocks respectively. ${ }^{20}$ First, all the seven countries show positive real exchange rate responses implying there is a depreciation to the shock. However, the responses for the depreciation last for only as short as 5 quarters (for Germany and USA) and for only as long as 20 quarters (for France and Italy). Such positive responses are followed by negative responses (appreciation) and positive responses and so forth. However, the amplitudes of those responses (positive and negative) start to die away and gradually diminish to zero (as fast as 25 quarters in Germany) across most of the countries (except for Japan and UK) as time elapses. Therefore, this study can claim that, in general, there is no long-run effect of nominal shocks on the real exchange rate even with the alternative restriction employed here.

According to figure 4 (for trade balance), even though most of the countries show bumpy responses, all show improvements in the trade balance thanks to the depreciation of the currency and dominant expenditureswitching effect. However the improvements do not last long across the countries mainly due to the interactions of both the expenditure-switching and output effects. ${ }^{21}$ They last for only as short as 3 quarters in most of the countries except for Germany and Japan. Further, even though all the countries experience both improvement and deterioration in the trade balance as they move toward a long-run equilibrium, most of the countries have such responses gradually die away as time elapses except for Japan. Hence, this research can claim that once again there are no long-run effects on both the real exchange rate and the trade balance by such nominal shocks across the G-7 countries. This confirms previous research that shows the empirical validity of Purchasing Power Parity in the long run and the long-run neutrality hypothesis in the open macroeconomic framework, whereas it is in contrast to many others. (Fisher and Seater 1993, Prasad and Gable 1998, Fisher and Huh 2002, Coe and Nason 2003) 


\section{FORECAST ERROR VARIANCE DECOMPOSITIONS}

Table 3-a: Forecast Error Variance Decomposition - Real Exchange Rate

\begin{tabular}{|c|c|c|c|c|c|c|c|}
\hline $\begin{array}{c}\text { Horizon } \\
\text { (quarters) }\end{array}$ & Canada & France & Germany & Italy & Japan & UK & USA \\
\hline 1 & 1.25 & 16.85 & 0.54 & 10.68 & 0.38 & 0.89 & 5.77 \\
2 & 2.54 & 14.78 & 0.86 & 5.07 & 0.17 & 0.39 & 4.10 \\
3 & 2.87 & 12.81 & 0.51 & 2.99 & 0.12 & 0.29 & 2.81 \\
4 & 3.06 & 11.43 & 0.40 & 2.12 & 0.09 & 0.28 & 2.04 \\
5 & 3.08 & 10.36 & 0.35 & 1.72 & 0.07 & 0.32 & 1.57 \\
10 & 2.01 & 7.27 & 0.18 & 0.92 & 0.04 & 0.15 & 0.72 \\
30 & 0.62 & 2.79 & 0.06 & 0.33 & 0.01 & 0.04 & 0.23 \\
50 & 0.35 & 1.50 & 0.03 & 0.20 & 0.01 & 0.02 & 0.13 \\
\hline
\end{tabular}

Table 3-b: Forecast Error Variance Decomposition - Trade Balance

\begin{tabular}{|c|c|c|c|c|c|c|c|}
\hline $\begin{array}{c}\text { Horizon } \\
\text { (quarters) }\end{array}$ & Canada & France & Germany & Italy & Japan & UK & USA \\
\hline 1 & 11.25 & 6.53 & 5.62 & 3.69 & 3.84 & 3.11 & 0.43 \\
2 & 7.82 & 7.06 & 3.79 & 4.07 & 2.53 & 1.01 & 1.14 \\
3 & 5.37 & 7.97 & 3.43 & 2.86 & 1.56 & 2.23 & 0.86 \\
4 & 3.88 & 8.00 & 2.73 & 2.62 & 1.22 & 2.04 & 0.73 \\
5 & 3.02 & 7.81 & 2.18 & 2.32 & 0.96 & 1.56 & 0.62 \\
10 & 1.47 & 6.09 & 1.00 & 1.42 & 0.50 & 0.65 & 0.36 \\
30 & 0.48 & 2.40 & 0.30 & 0.54 & 0.18 & 0.18 & 0.13 \\
50 & 0.29 & 1.32 & 0.17 & 0.33 & 0.11 & 0.10 & 0.08 \\
\hline
\end{tabular}

Figure 5-a. Forecast Error Variance Decomposition - Real Exchange Rate

Canada

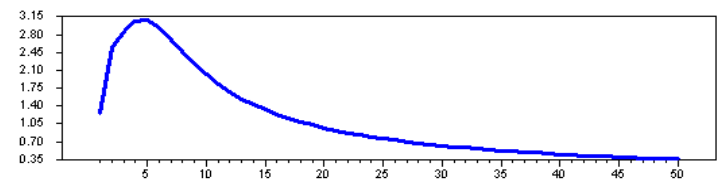

France

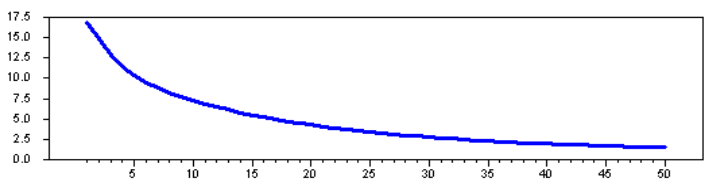

Germany

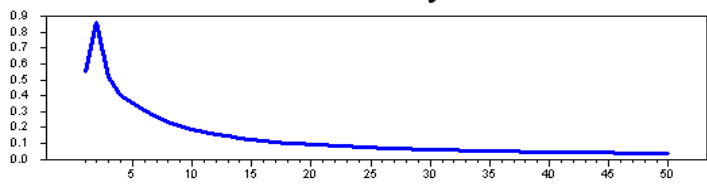

Italy

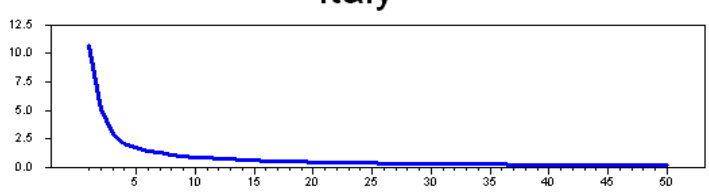

Japan

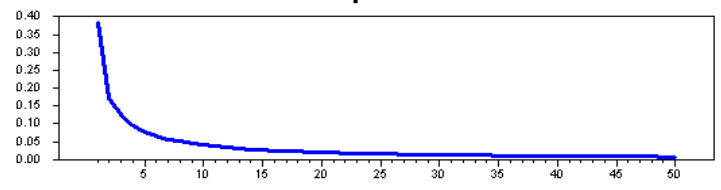

UK

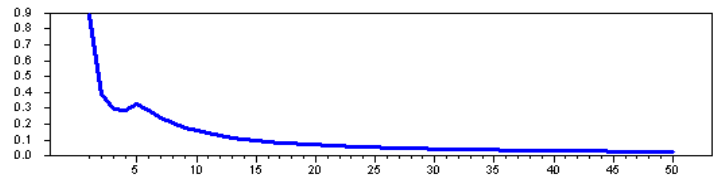

USA

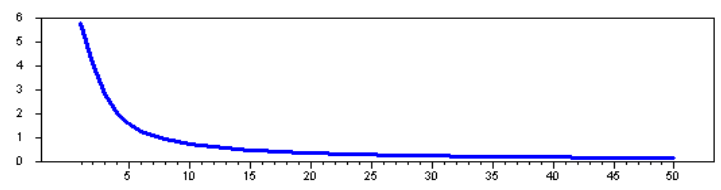


Figure 5-b. Forecast Error Variance Decomposition - Trade Balance
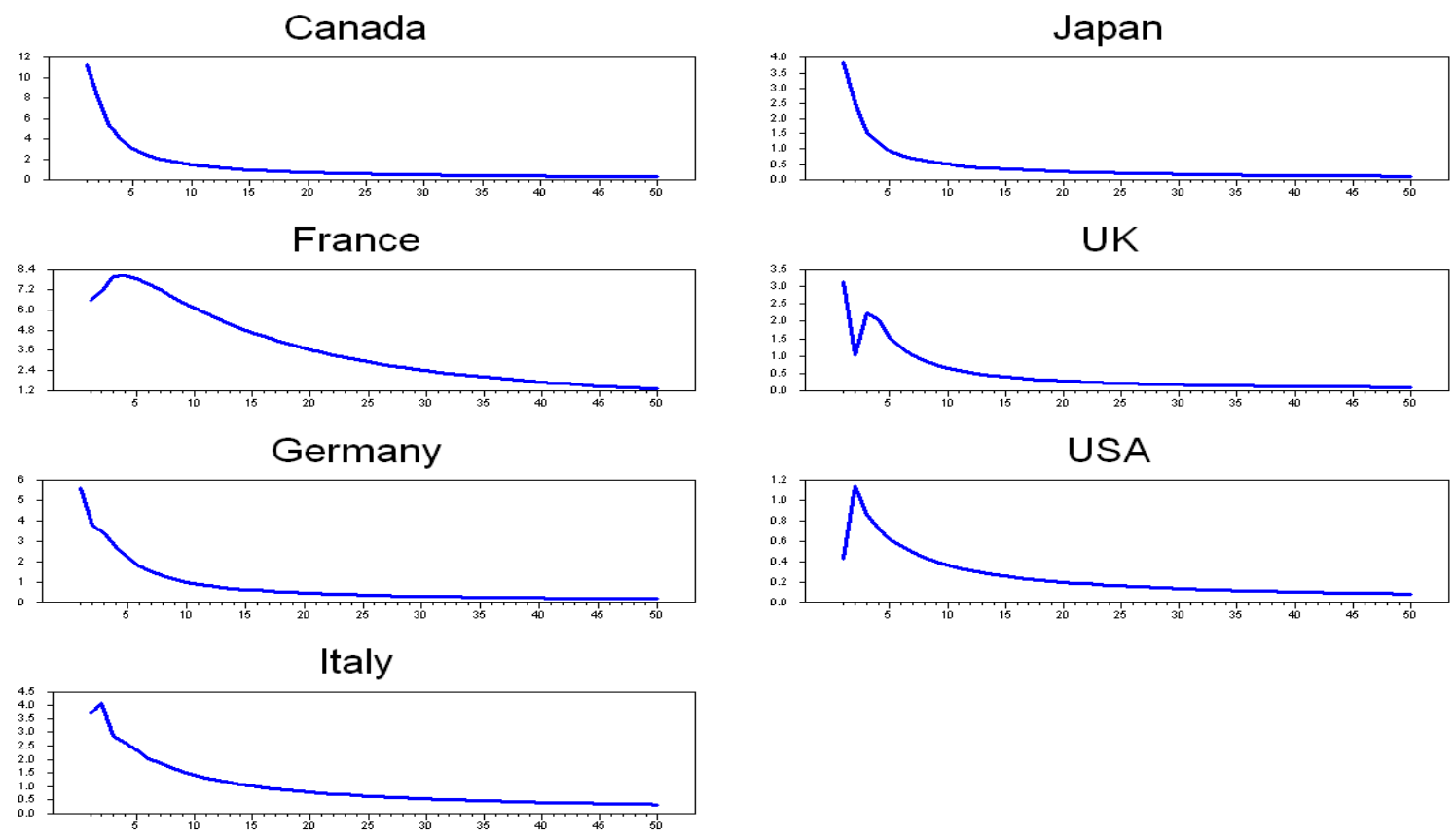

The variance decompositions tell the relative importance of the shocks in the variations of the variables of interest. Table 3-a and -b (Figure 5-a and -b) show the forecast error variance decompositions at 50 horizons for the two variables (real exchange rate and trade balance) of the G-7 countries. Even though there are significant differences in the importance of the monetary shock in accounting for the variations across the countries, the real effects of such monetary shocks diminish eventually as the output price adjusts to the shocks. The results have less than $1 \%$ in the contributions of the shock to the real exchange rate at forecast horizons of 50 quarters across all the countries except for France. (Table 3-a) Similar contributions can be found in accounting for variations of the trade balance in table 3-b. Thus, such nominal shocks do not have any long-run effects on real variables such as real exchange rate and trade balance even though it is somewhat important in the short run.

\section{CONCLUSION}

There is enough evidence of monetary transmission to real economic activities in the short run even though it is still debatable about its long-run effect. Many show a long-run neutrality of nominal shocks while others do not. In this study, six variable-VAR models of G-7 countries are built in an attempt to show the empirical validity of the long-run neutrality of nominal shocks (monetary shocks) in an open macroeconomic framework while giving most of the attention to the responses in the real exchange rate and trade balance. ${ }^{22}$

The results in this paper are robust to critiques (by employing both long-run and short-run restrictions) and contradict the findings by Fisher and Seater (1993), Fisher and Huh (2002), Coe and Nason (2003) and many others. Therefore, such a long-run neutrality hypothesis is said to be robust and persistent, which is in line with many previous arguments that have become a long-run feature of open macroeconomics.

\section{SUGGESTIONS FOR FUTURE RESEARCH}

Even though the findings in this paper are consistent with many previous studies in a framework of open macroeconomics, the results contain wide variations in the responses of the variables to the shocks across the countries. Hence, it is worth investigating those heterogeneous economic environments that cause such variations across the countries. 


\section{ENDNOTES}

${ }^{1}$ This long-run neutrality restriction was well explained by Shapiro and Watson (1988) and Blanchard and Quah (1989). Lucas (1996) also provides an excellent description about the neutrality of money in his Nobel lecture.

${ }^{2}$ They show the rejection of the long-run $n$

eutrality using a bivariate (money and output) ARIMA framework

${ }^{3}$ Refer to Christiano, Eichenbaum, and Evans (1997) for a detailed description of the restriction.

${ }^{4}$ Refer to Fisher and Huh (2002) for more discussions of the long-run neutrality hypothesis in an open macroeconomic framework.

${ }^{5}$ Long-run PPP implies that there is no long-run effect on real exchange rate by shocks to nominal variables such as money supply.

${ }^{6}$ Prasad (1999), and Fisher and Huh (2002), respectively, employ only real output, real exchange rate and trade balance in their models. In addition, the stylized facts about the effects of expansionary money supply shocks are as follows: (i) output increases for a couple of years; (ii) the interest rate falls down initially followed by gradual recovery; and (iii) price level is sticky for a couple of years to the shocks.

${ }^{7}$ The empirical model here follows the works of Lastrapes $(1992,1998)$ frequently cited in studies using VAR frameworks with a long-run neutrality hypothesis.

${ }^{8}$ The exchange rate for the US is against the UK. No qualitative differences are found for the US when the exchange rates vis-àvis other major foreign currencies are used.

${ }^{9}$ Both M1 and M2 are used for aggregate monetary stocks to see if there are any discrepancies. M3 is also used for some countries when the data for M2 are not available. However, no qualitative differences are found across the measurements.

${ }^{10}$ In the interests of conserving space, the difference is not provided here; however, it is obtainable from the author upon request.

${ }^{11}$ Each figure displays the estimated response functions along with simulated standard error bands to account for the precision of the estimates. The standard error bands are obtained using conventional Monte Carlo integration techniques.

12 The discussions of the responses in the remaining variables and variations in the responses of the variables across the countries are avoided in this research even though it is worth doing so, because it is beyond the main purpose of this paper.

${ }^{13}$ It is supposed to show longer positive effects on trade balance when output effect is controlled.

${ }^{14}$ This is an advantage for the short-run restriction because there are some economists who are against differencing the variables arguing that valuable information concerning the corelationships among the variables may be thrown away in the process. (Sims, 1980)

${ }^{15}$ Each symbol indicates the same variable used in the preceding section. However, $M_{t}$ contains both M1 and M2/M3.

${ }^{16}$ Due to some negative values for trade deficit, the trade balance variable does not take the logarithms.

${ }^{17} \mathrm{Kim}$ (1999) argues that the monetary authority is assumed to set the interest rate after observing the current value of money, but not the current values of output nor the price level. He further assumes there are information delays in data on output and price level.

${ }^{18}$ Interest rate does not take the logarithms, but it is expressed as a percentage.

${ }^{19}$ Further, any shocks to variables in $Z_{1 t}$ affect the $M_{t}$ contemporaneously implying that $D_{31} \neq 0$.

${ }^{20}$ To conserve space, this paper reports only responses of the real exchange rate and trade balance. However the responses of the other aggregate variables remain consistent with previous findings, though.

${ }^{21}$ The output effect is not controlled here because the main purpose of the study is to identify the persistence of nominal shocks on the variables in an open macroeconomic framework. It is more believed that both the output and depreciation effects need to be considered to better account for the persistence of the shocks.

${ }^{22}$ Even with criticisms such as that any elaborate structural equations with more variables often fail to identify statistically significant impulse-response functions and reach less persuasive conclusions, this paper employs more variables here because the model can still be very useful in validating several presumptions (richer set of results pertaining to multiple variables) in openeconomy macroeconomics with a minimum of arbitrariness as long as the nominal shocks are properly identified.

\section{REFERENCES}

1. Andrews, D. W. K., Power in Econometric Applications, Econometrica, 57, pp. 1059-90, 1989.

2. Boschen, J. F. and Otrok, C. M., Long-Run Neutrality and Superneutrality in an ARIMA Framework: Comment, American Economic Review, 84, pp. 1470-73, 1994.

3. Blanchard, O. J. and Quah, D., The Dynamic Effects of Aggregate Demand and Supply Disturbances, American Economic Review, 79, pp. 655-73, 1989.

4. Christiano, L. J. and Eichenbaum, M., Liquidity Effects and the Monetary Transmission Mechanism, American Economic Review, 82, pp. 346-53, 1992. 
5. Christiano, L. J., Eichenbaum, M. and Evans, C. L., Sticky Price and Limited Participation Models of Money: A Comparison, European Economic Review, 41, pp. 1201-49, 1997.

6. Christiano, L. J., Eichenbaum, M. and Evans, C. L., Monetary Policy Shocks: What Have We Learned and to What End? Handbook of Macroeconomics, 1A, pp. 65-148, 1999.

7. Clarida, R. and Gali, J., Sources of Real Exchange Rate Fluctuations: How Important Are Nominal Shocks? Carnegie-Rochester Conference Series on Public Policy, 14, pp. 1-56, 1994.

8. Cooley, T. F. and Dwyer, M., Business Cycle Analysis without Much Theory: A Look at Structural VARs, Journal of Econometrics, 83, pp. 57-88, 1998.

9. Coe, P. J. and Nason J. M., The Long-Horizon Regression Approach to Monetary Neutrality: How Should the Evidence Be Interpreted? Economics Letters, 78, pp. 51-56, 2003.

10. Faust, J. and Leeper E. M., When Do Long-run Identifying Restrictions Give Reliable Results? Journal of Business and Economics Statistics, July, 1997.

11. Fisher, L. A. and Huh, H-S., Real Exchange Rates, Trade Balances and Nominal Shocks: Evidence for the G-7, Journal of International Money and Finance, 21, pp. 497-518, 2002.

12. Fisher, M. E. and Seater, J. J., Long-Run Neutrality and Superneutrality in an ARIMA Framework, American Economic Review, 83, pp. 402-15, 1993.

13. Gali, J., How Well Does the IS-LM Model Fit Postwar U.S. Data? Quarterly Journal of Economics, 107, pp. 709-38, 1992.

14. Haug, A. A. and Lucas, R. F., Long-Run Neutrality and Superneutrality in an ARIMA Framework : Comment, American Economic Review, 87, pp. 756-59, 1997.

15. Kim, D-K., Real Wage and Nominal Shock: Evidence from Pacific-Rim Countries, International Advances in Economic Research, 11(3), pp.249-55, 2005.

16. Kim, S., Do Monetary Policy Shocks Matter in the G-7 Countries? Using Common Identifying Assumptions about Monetary Policy across Countries, Journal of International Economics, 48, pp. 387412, 1999.

17. King, R. G. and Watson, M. W., Testing Long-Run Neutrality, Federal Reserve Bank of Richmond Economic Quarterly, 83, pp. 69-101, 1997.

18. Lastrapes, W. D., Sources of Fluctuations in Real and Nominal Exchange Rates, Review of Economics and Statistics, 74, pp. 530-39, 1992.

19. Lastrapes, W. D., The Dynamic Effects of Money: Combining Short-Run and Long-Run Identifying Restrictions Using Bayesian Techniques, Review of Economics and Statistics, 80, pp. 588-99, 1998.

20. Lastrapes, W. D., The Real Price of Housing and Money Supply Shocks: Time-Series Evidence and Theoretical Simulation, Journal of Housing Economics, 11, pp. 40-74, 2002.

21. Lee, J-W. and Chinn, M., The Current Account and the Real Exchange Rate: A Structural VAR Analysis of Major Currencies, NBER Working Paper, No. 6495, 1998.

22. Lucas, R. E., Nobel Lecture: Monetary Neutrality, Journal of Political Economy, 104, pp. 661-82, 1996.

23. Prasad, E., International Trade and the Business Cycle, Economic Journal, 109, pp. 588-606, 1999.

24. Prasad, E. and Gable, J., International Evidence on the Determinants of Trade Dynamics, IMF Staff Papers, 45, pp. 401-39, 1998.

25. Shappiro, M. and Watson, M., Sources of Business Cycle Fluctuations, In Stanley Fisher, editor, NBER Macroeconomics Annual, Cambridge : MIT Press, pp. 111-48, 1988.

26. Sims, C., Macroeconomics and Reality, Econometrica, 48, pp. 1-48, 1980.

27. Sims, C. and Zha, T., Does Monetary Policy Generate Recessions? unpublished manuscript, Yale University, 1995. 


\section{APPENDIX}

Description Of Data From OECD Main Economic Indicators For G-7 Countries

\begin{tabular}{|c|c|c|c|c|c|c|}
\hline & $\begin{array}{c}\text { Exchange } \\
\text { Rate }\end{array}$ & $\begin{array}{c}\text { Trade } \\
\text { Balance }\end{array}$ & Nominal GDP & Interest Rate & Money Supply & Price Index \\
\hline Canada & canusxav & canftbsu & cangdps & $\begin{array}{c}\text { cancd90d } \\
\text { (canfbond) }\end{array}$ & $\begin{array}{c}\text { canm1ind } \\
\text { (canm2s) }\end{array}$ & cancpi \\
\hline France & frausxav & fraftbsu & fragdpvs & $\begin{array}{c}\text { frapibor } \\
\text { (frabondp) }\end{array}$ & $\begin{array}{c}\text { fram1ind } \\
\text { (fram1qs) }\end{array}$ & fracpi \\
\hline Germany & deuusxav & deuftbsu & deugdps & $\begin{array}{c}\text { deufibor } \\
\text { (deumbond) }\end{array}$ & $\begin{array}{c}\text { deum1ind } \\
\text { (deum1qs) }\end{array}$ & deucpitm \\
\hline Italy & itausxav & itaftbsu & itagdpvs & $\begin{array}{c}\text { itaibor } \\
\text { (itagbond) }\end{array}$ & $\begin{array}{c}\text { itam1ind } \\
\text { (itam1qs) }\end{array}$ & itacpi \\
\hline Japan & jpnusxav & jpnftbsu & jpngdps & $\begin{array}{c}\text { jpncrdep } \\
\text { (jpngbond) }\end{array}$ & $\begin{array}{c}\text { jpnm1ind } \\
\text { (jpnm1qs) }\end{array}$ & jpncpinf \\
\hline UK & gbrusxav & gbrftbsu & gbrgdps & $\begin{array}{c}\text { gbrib3mt } \\
\text { (gbrbond) }\end{array}$ & $\begin{array}{c}\text { gbrm2ind } \\
\text { (gbrm2) }\end{array}$ & gbrcpi \\
\hline USA & gbrusxav & usaftbsf & usagdps & $\begin{array}{c}\text { usacdrat } \\
\text { (usagbond) }\end{array}$ & $\begin{array}{c}\text { usam1ind } \\
\text { (usam1qs) }\end{array}$ & usacpi \\
\hline
\end{tabular}

Notes: The symbols in parentheses of interest rate and money supply columns are long-term interest rates and M2/M3, respectively.

\section{NOTES}




\section{NOTES}

